\title{
KONSEP DIRI (SELF CONCEPT) DAN KOMUNIKASI INTERPERSONAL DALAM PENDAMPINGAN PADA SISWA SMP SE KOTA YOGYAKARTA
}

\author{
Pratiwi Wahyu Widiarti \\ Pratiwi_ww@uny.ac.id \\ Jurusan Ilmu Komunikasi FIS UNY
}

\begin{abstract}
This study aims to determine, the self-concept of junior high school students in the city of Yogyakarta and description of the mentoring model for junior high school students in Yogyakarta city based on adolescent self concept.The research method used quantitative method, with descriptive statistical technique. The population of this research is all junior high school students in Yogyakarta city from 15 State Junior High School and 42 Private Junior High. The results is first, the self-concept of students is balanced between those who have low self-concept (222 people: 49.4\%), with high selfconcept (227 people: 50,6\%). Second, from the self concept aspects, the results obtained, have: a) high self-concept/academic self as much as 262 students (58.4\%); b) family self concept as high as 257 students (57.2\%); c) high physical self-concept, ie 250 students (55.7\%); d) low self-concept moral ethics there are 220 students (49\%); e) low social self-concept there are 220 students (49\%); f) Low self-concept personal there are 216 students (48.1\%). Third, the low-tendentious concept of self is ethical-moral, social and personal, then approaches are used for the assistance: a) from the side of interpersonal communication: Self-fulfilling prophecy; opened self; self confidence; and selectivity; $b$ ) in terms of interaction style, by developing an enabling interaction style; c) in terms of guidance and counseling services by forming individual guidance and group guidance.
\end{abstract}

\begin{abstract}
Abstrak
Penelitian ini bertujuan untuk mengetahui konsep diri remaja siswa SMP sekota Yogyakarta dan deskripsi model pendampingan bagi remaja siswa SMP se kota Yogyakarta berdasar konsep diri remaja. Melalui metode kuantitatif, dengan teknik statistik deskriptif. Populasi penelitian ini adalah seluruh siswa SMP se kota Yogyakarta dari 15 SMP Negeri dan 42 SMP Swasta. Hasil penelitian adalah, pertama, konsep diri siswa berimbang antara yang memiliki konsep diri yang rendah (222 orang: 49.4\%), dengan yang memiliki konsep diri yang tinggi (yaitu 227 orang: 50.6\%). Kedua, dari aspek-aspek konsep diri, diperoleh hasil, yang memiliki: a) konsep diri kerja/akademik yang tinggi sebanyak 262 siswa (58.4\%); b) konsep diri keluarga yang tinggi sebanyak 257 siswa (57.2\%); c) konsepdiri fisik yang tinggi, yaitu 250 siswa (55.7\%); d) konsepdiri etik moral yang rendah ada22o siswa (49\%); e) konsep diri sosial yang rendah ada 220 siswa (49\%); f) konsep diri personal yang rendah ada 216 siswa (48.1 persen). Ketiga, konsep diri yang cenderung rendah adalah konsep diri etik-moral, sosial dan personal, maka digunakan pendekatan bagi pendamping: a) dari sisi komunikasi interpersonal: Nubuat yang dipenuhi sendiri; membuka diri; percaya diri; dan selektivitas; b) dari sisi gaya interaksi, dengan mengembangkan gaya interaksi yang mendorong (enabling); c) dari sisi layanan bimbingan dan konseling dengan membentuk bimbingan kelompok dan bimbingan individual.
\end{abstract}

Keywords: Self Concept, Interpersonal Communication, Counseling 


\section{PENDAHULUAN}

Masa remaja adalah masa transisi dari masa kanak-kanak menuju dewasa. Rentang masa remaja cukup panjang, terutama di era dan area negara industri maupun di negara sedang berkembang, yaitu berkisar usia 11/12 tahun-21/22 tahun. Di Indonesia kaum muda yang di dalamnya tergolong ada remaja; cukup banyak persentasenya, sekitar $30 \%$ an adalah mereka yang berusia muda. Kaum muda terutama remaja, akan menghadapi banyak tugas-tugas perkembangan yang harus dilaluinya. Menurut Havighurst dalam Hurlock (1991) ada sekitar 7 tugas perkembangan yang harus dihadapi seorang remaja. Tercapainya tugastugas perkembangan ini juga akan sangat dipengaruhi oleh lingkungan dan kultur.

Dalammenghadapitugas-tugastersebut, ada remaja yang mampu menghadapinya, namun juga ada yang kurang atau tidak mampu menghadapi.mampu menghadapi, biasanya akan melakukan hal-hal yang sifatnya kontradiktif dan bersifat negatif. Jika demikian, ini akan menimbulkan persoalan bagi remaja sendiri maupun lingkungannya. Masa remaja juga sering disebut masa krisis, beberapa hal yang menimbulkan krisis pada remaja antara lain terlihat dari hasil penelitian Pam Nilan (2013) pada remaja di Indonesia, antara lain bagi remaja Indonesia, yang menimbulkan masalah di usia remaja adalah 1) seks bebas (free seks) atau pergaulan bebas, yaitu $50 \%$ dari subjek remaja yang diteliti ( $\mathrm{N}$ : 3565 remaja). 2) 40\% remaja menyebutkan narkoba dan minuman keras adalah masalah bagi remaja; 3) hanya $20 \%$ remaja yang men'cemas'kan ketiadaan pekerjaan atau masalah ekonomi. Penelitian Pam Nelan ini, sekitar $61,7 \%$ dari respondennya sedang bersekolah setaraf SMP.

Penelitian di Barat pada anak-anak usia remaja awal (11-15 tahun), ditemukan persoalan-persoalan tentang bagaimana remaja menghadapi perkembangan dirinya terutama dalam perkembangan fisiknya. Persoalan yang muncul, adalah ada $75 \%$ anak-anak usia 8-9 tahun yang menyatakan mereka menyukai penampilannya, namun saat usia 12-13 tahun, terutama pada gadis remaja yang menyukai penampilannya turun menjadi 56\%. Anak-anak perempuan usia 9 tahun, dilaporkan melakukan diet, sedang remaja yang ada di kelas VIII (kelas 2 SMP) $80 \%$ nya juga melakukan diet. Selanjutnya ada sekitar 7 juta remaja perempuan dan perempuan dewasa mengalami gangguan makan (eating disorders), sementara anak laki-laki dan laki-lakidewasayang mengalami hal tersebut hanya 1 juta. 10\% nya terjadi pada usia 10 tahun atau lebih muda, sedang $33 \%$ nya di usia 11-15 tahun. Hasil yang lain, ada sebanyak 20\% perempuan usia mahasiswa adalah pengidap bulimia. Selain itu satu dari 3 remaja perempuan kelas 9-12 (setara SMA) menganggap dirinya mengalami kegemukan, dan 6o \% nya selalu mencoba menurunkan berat badan. (Journal Writing Improves SelfEsteem, 2013)

Dari persoalan yang dipikirkan dan dihadapi remaja baik yang di dunia Barat maupun di Indonesia, nampak ada suatu kegamangan dalam menghadapi hidup pada masa ini, terutama kecemasan diawali dari dalam diri sendiri, yaitu kecemasan pada tubuh / fisik yang berkembang, kemudian setelah menghadapi persoalan di dalam diri sendiri, remaja juga perlu menyesuaikan diri dengan hal-hal di luar dirinya, masalah relasi dengan orang lain, terutama orangtua dan juga teman-teman sebayanya. Hal ini masih ditambah dengan bagaimana remaja belajar menyesuaikan diri dengan orang lain, dengan norma dan kultur yang melingkupinya.

Hal-hal yang dihadapi oleh remaja, sebagian besar menyangkut tentang dirinya. Sementaradiri(self) terbentukdenganadanya konsep tentang diri (self concept). Indikasi masalah-masalah diri pribadi maupun diri dengan lingkungannya menunjukkan bahwa banyak remaja memiliki konsep diri yang kurang (rendah) atau belum memahami bagaimana konsep dirinya sendiri. Konsep diri merupakan gambaran menyeluruh tentang kemampuan dan sifat-sifat seseorang (Papalia \& Olds, 1996). Menurut Fittz (Hendriati Agustiani: 2009) keseluruhan kesadaran atau persepsi seseorang tentang dirinya sendiri merupakan gambaran tentang diri atau konsep diri individu. Fitts juga 
menyatakan, bahwa konsep diri berpengaruh kuatterhadaptingkahlakuseseorang. Dengan mengetahui konsep diri seseorang, akan lebih mudah meramalkan dan memahami tingkahlaku orang tersebut. Jika remaja menggambarkan dirinya sebagai seseorang yang positif, maka hal ini disebabkan oleh penilaian dirinya sendiri serta penilaian dirinya oleh orang lain bersifat positif. Hal yang sebaliknya dapat terjadi. Jika seseorang mempersepsikan dirinya sebagai orang yang inferior dibandingkan dengan orang lain, walaupun hal ini belum tentu benar, biasanya tingkah laku yang ditampilkan akan berhubungan dengan kekurangan yang dipersepsinya secara subjektif tersebut (Hendriati Agustiani, 2009).

Menilik adanya persoalan remaja terutama remaja yang duduk di bangku sekolah SMP yang berkisar tentang diri dan penyesuaian diri dengan lingkungannya, maka penulis tertarik meneliti konsep diri pada siswa SMP se kota Yogyakarta, dengan anggapan, siswa-siswa tersebut juga mengalami persoalan tentang dirinya, dan berkait dengan konsep diri. Penelitian ini dilakukan untuk mengetahui bagaimana konsep diri remaja, dan untuk tujuan selanjutnya, yaitu menemukan model pendampingan yang sesuai bagi remaja usia SMP se Yogyakarta berdasar temuan tentang konsep diri remaja ini.

Penelitian ini mengidentifikasi bahwa terdapat persoalan-persoalan dalam diri remaja terutama persoalan konsep diri yang memang sedang dalam proses pembentukan dalam perkembangan rentang hidup. Dengan mengetahui konsep diri para remaja siswa SMP se Yogyakarta, dapat dibuat pemetaan konsep diri remaja SMP dan akhirnya dapat digunakan untuk menemukan model pendampingan berdasar konsep diri remaja. Sesuai dengan latar belakang penelitian dan identifikasi permasalahan, maka penulis merumuskan permasalahan sebagai berikut, bagaimana konsep diri remaja siswa SMP se kota Yogyakarta? Bagaimana deskripsi model pendampingan bagi remaja siswa SMP se kota Yogyakarta berdasar konsep diri remaja?

\section{KAJIAN PUSTAKA}

\section{Konsep Diri}

Konsep diri adalah pemahaman tentang diri sendiri yang timbul akibat interaksi dengan orang lain. Konsep diri merupakan faktoryang menentukan (determinan) dalam komunikasi kita dengan orang lain (Riswandi, 2013: 64). Konsep diri adalah pandangan dan perasaan tentang diri kita. Persepsi tentang diri ini bisa bersifat psikologis, sosial dan fisis, menurut William D Brooks dalam Jalaludin Rakhmat (2015: 98).

Kebanyakan ahli-ahi tentang diri setuju, bahwa konsep diri secara jelas dapat terdiferensiasikan dan terstruktur, yang merupakan suatu keseluruhan yang stabil. Sepanjang kehidupan, konsep diri berkembang dan berubah secara berkelanjutan, meskipun sulit untuk membedakanantaraperkembangandanperubahan konsep diri (Fittz, 1972: 35). Dengan adanya perkembangan dan perubahan tersebut, dapatlah diterima pendapat Rogers (Hall \& Lindzey, 1978: 499), bahwa struktur diri berkembang dan berubah seiring waktu. Di masa kanak-kanak awal, ada kecenderungan perkembangan yang berasal dari citra diri (self image) yang positif atau negatif. Selanjutnya diri terbentuk melalui interaksi dengan lingkungan, khususnya lingkungan yang terdiri dari orang-orang yang signifikan (orangtua, sibling). Pada saat anak memiliki sensitifitassosialdisertai kemampuan kognisi dan kemampuan perseptualnya menjadi matang, konsep diri menjadi berbeda dan lebih kompleks.

Berk (1996: 280, 355, 467) menjelaskan bahwa perkembangan konsep diri diawali dari usia 2 tahun (ada rekognisi diridengan melihat dirinya di kaca, foto, videotape); masa kanak-kanak awal (konsep dirinya bersifat kongkrit, biasanya berdasar karakteristik nama, penampilan fisik, barang-barang milik dan tingkahlaku sehari-hari); masa kanak-kanak pertengahan (ada transformasi dalam pemahaman diri, mulai menjelaskan diri dengan istilah-istilah sifat kepribadian, mulai dapat membandingkan karakteristik dirinya dengan peer-nya). Faktor-faktor yang 
bertanggungjawab terhadap perubahan konsep diri ini dapat dialamatkan pada perkembangan kognitif yang pasti mempengaruhi perubahan struktur diri. Isi dari perkembangan konsep diri paling banyak berasal dari interaksi dengan orang lain, yang dijelaskan oleh Mead mengenai diri adalah 'suatu campuran tentang apa yang dipikirkan orang-orang signifikan di sekitar kita tentang kita'. Hal ini memperlihatkan bahwa ketrampilan mengambil perspektif (perspektif-taking) munculselamamasaanak, khususnya kemampuan mengimajinasikan apa yang dipikirkan orang lain, memainkan peranan penting dalam perkembangan diripsikologisnya; masa remaja (pendefinisiandirimenjadilebihselektif, meskipun orangtua tetap berpengaruh, kelompok peers menjadi lebih penting di usia 8-15 tahun, konsep diri menjadi meningkat dengan memperoleh umpan balik dari teman dekat).

Menurut Harter, 1990 (dalam Steinberg, 1993: 256) anak-anak dalam menjelaskan dirinya lebih bersifat sederhana dan kongkrit dibandingkan remaja yang menjelaskan dirinya lebih kompleks dan abstrak. Perkembangan konsep diri pada masa remaja diteliti oleh Livesley \& Bromley, 1973; Marsh, 1989; Montemayor \& Eisen, 1977; Harter, 1990; Marsh, 1989 (Steinberg, 1993: 256), dengan memaparkan hasil bahwa konsep diri masa remaja berbeda strukturnya dan lebih terorganisir dibanding masa anak-anak. Contoh, bila anak mengemukakan statement tentang traitsnya maka nampak kontradiktif: "Saya bersahabat, saya pemalu". Sedang statement remaja lebih terorganisir: "Saya pemalu saat bertemu pertama kali dengan orang lain".

\section{Dimensi Konsep Diri}

Hall dan Lindzey (1970) (Fittz, 1971: 14) mengemukakan bahwa diri mempunyai dua makna yang berbeda. Sikap, perasaan, persepsi dan evaluasi adalah tentang diri sebagai objek (self-as-object); sementara berpikir, mengamati dan melakukan aktivitas merupakan diri sebagai proses (self-as-process). Diri secara keseluruhan, yang dialami oleh individu, sering disebut 'diri-fenomenal'. Diri fenomenal ini adalah diri yang diamati, dialami dan dinilai oleh individu itu sendiri; inilah diri yang disadari. Jumlah keseluruhan dari semua kesadaran ini atau persepsi-persepsi tentang citra dirinyaitulah konsep dirinya

Konsep diri ini melebur bersama dalam suatu kesatuan dan keseluruhan yang dinamik. Masing-masing bagian berinteraksi secara bebas-kohesif satu sama lain. Bagian-bagian atau keseluruhan tersebut berinteraksi dengan aspek eksternal dari dunia fenomenalnya.

\section{Dimensi Internal}

Diri-Identitas (The Identity Self); Diri Tingkah-Laku (The Behavioral Self); Diri Penilaian (The Judging Self)

\section{Dimensi Eksternal}

Menurut Sarbin (1952) (Fittz, 1971: 20), kelompok-kelompok sub-diri secara bersama-sama membentuk diri-total (total self). Sub-sub diri ini merupakan kerangka eksternal, sebagailawandimensi internal (diri identitas, diri tingkahlaku, diri penilaian). Sub-sub diri eksternal ini adalah : diri fisik (physical-self); diri moral-etik (moral ethical self); diri personal/pribadi (personal self); diri keluarga (family self); dan diri sosial (social self); diri akademik/kerja (academic/ work self).

Dari dimensi eksternal terdapat sub-sub diri sebagai berikut:Diri Fisik (Physical Self). Merupakan persepsi seseorang terhadap keadaan fisik, kesehatan, penampilan diri dan gerak motoriknya.

Diri Etik Moral (Moral-Ethical Self). Diri etik moral merupakan persepsi individu tentang dirinya ditinjau dari standar pertimbangan nilai-nilai moral dan etika. Dalam hal ini ditinjau dari hubungan orang dengan Tuhan, rasa puas individu terhadap kehidupan, beragamnya nilai-nilai moral yang dianut dan perasaan sebagai orang baik atau orang buruk 
Diri Personal (Personal Self). Diri personal merupakan perasaan individu terhadap nilai-nilai pribadi, terlepas dari keadaan fisik dan hubungannya dengan orang lain, sejauh mana individu merasa adekuat sebagai pribadi.

Diri Keluarga (Family Self). Diri keluarga merupakan perasaan dan harga diri individu sebagai anggota keluarga dan teman-teman dekatnya. Sejauhmana dirinya merasa adekuat sebagai anggota keluarga dan temanteman dekatnya

Diri Sosial (Social Self). Diri sosial merupakan penilaian individu terhadap dirinya dalam interaksi dengan orang lain dalam lingkungan yang lebih luas

Diri Akademik/Kerja (Academic/Work Self). Diri Akademi atau kerja merupakan penilaian yang berkaitan dengan penilaian keterampilan dan prestasi akademik. Bagaimana orang lain merasakan kehadiran seseorang di sekolah atau tempat kerja dan bagaimana seseorang melihat orang lain pada situasi tersebut.

Faktor-faktor yang mempengaruhi konsep diri menurut Jalaludin Rakhmat (2015, 99) adalah:a) orang lain; b) kelompokrujukan (reference group). Selanjutnya ada 5 petunjuk orang yang memiliki konsep diri positif: Memiliki keyakinan untuk menyelesaikan masalah; Merasa setara dengan orang lain; Menerima pujian dari orang lain tanpa rasa malu; Memiliki kesadaran bahwa setiaporang mempunyai berbagai perasaan, keinginan dan perilaku yang tidak seluruhnya disetujui oleh masyarakat; Mampu memperbaiki diri karena ia sanggup mengungkapkan aspekaspek kepribadian yang tidak disukainya dan mengubahnya.Memiliki keyakinan untuk menyelesaikan masalah.

Sedangkan yang memiliki konsep diri negatif, ada 4 tanda yaitu:Peka pada kritik; Sangat responsif pada pujian; Cenderung merasatidakdiperhatikandantidakdisenangi oleh orang lain; Bersikap pesimistis terhadap kompetisi, dia enggan untuk bersaing dengan orang lain dalam hal prestasi.

\section{Model Pendampingan Remaja}

Model pendampingan pada remaja dapat ditinjau dari berbagai sisi, misalnya dari sisi komunikasi interpersonal, gaya interaksi pendamping, dalam hal ini bisa guru atau orangtua, atau teman sebaya yang lebih tua, atau dari sisi bimbingan dan konseling.

Dari sisi komunikasi interpersonal perlu memperhatikan aspek-aspek yang ada dalam komunikasi interpersonal, yaitu: a) Atraksi interpersonal, yang terdiri dari faktorfaktor personal yang mempengaruhi atraksi interpersonal dan faktor-faktor situasional (Riswandi, 2013: 65-69). Selanjutnya konsep diri memiliki pengaruh pada komunikasi interpersonal yaitu: a) nubuat yang dipenuhi sendiri; b) membuka diri; c) percaya diri dan d) selektivitas (Jalaludin Rakhmat, 2015: 99108).

Dari sisi gaya interaksi (interaction style) ada seorang ahli Hauser (Hauser, et.al, 1984, dalam Papini, Archer, 1994: 49; Hauser \& Kliner, 1989, Hauser, Powers \& Noam, 1991 dalam Fittz, 1972: 348). Hauser melakukan penelitian gaya interaksi dengan remaja yaitu gaya interaksi enabling dan constraining, keduanya mengandung komponen kognitif dan afektif.

\section{Gaya Interaksi Mendorong (Enabling)}

Gaya interaksi mendorong (enabling) menyiratkan adanya dorongan pada remaja untuk mengekspresikan pikiran-pikiran dan persepsi-persepsi mereka. Gaya enablingyang kognitif meliputi: memfokuskan pada pemecahan masalah; mengikutsertakan dalam bereksplorasi tentang masalah-masalah remaja, menjelaskan sudut pandang individu pada teman yang lain. Gaya enabling yang afektif meliputi: adanya ekspresi empati dan penerimaan dari teman remaja ke yang lain dan sebaliknya.

\section{Gaya Interaksi Menghambat (Constraining)}

Gaya interaksi yang menghambat (constraining)menyiratkanadanyahambatan yang dilakukan orang dewasa dalam hal 
otonomi dan perbedaan (differentiation). Constraining yang kognitif meliputi: mengalihkan anggota kelompok remaja dari masalah-masalah yang mereka hadapi, tidak memberi (menyembunyikan) informasi pada remaja dan mengabaikan remaja maupun masalah-masalah remaja.Constraining yang afektif meliputi : penilaian yang berlebihan (bersifat negatif atau positif) terhadap remaja dan pandangan-pandangan mereka.

Selain dari gaya interaksi, juga dapat ditinjau dari sisi layanan pada siswa yang diadopsi dari domain BK (Bimbingan Konseling). Ada 4 teknik dalam BK (Nidya Damayanti: 2012) yaitu 1) Bimbingan Kelompok; 2) Penyuluhan Individu; 3) Bimbingan Lapangan; dan 4) Bimbingan Klasikal.

Bimbingan Kelompok. Dalam hal ini, bimbingan yang diberikan kepada siswa secara berkelompok dimana setiap masalah yang dihadapi di kelompok akan dibahas secara bersama-sama.

Penyuluhan Individu. B i $\mathrm{m}$ b i $\mathrm{n} \mathrm{g}$ a $\mathrm{n}$ diberikan kepada siswa secara perorangan dan pelaksanaannya dilakukan secara tatap muka langsung dengan siswa.

Bimbingan Lapangan. Bimbingan yang diberikan kepada siswa dengan melakukan kegiatan di luar kelas atau di luar ruangan.

Bimbingan Klasikal. Bimbingan yang diberikan kepada siswa yang pelaksanaanya dilakukan di dalam kelas.

\section{METODE}

Penelitian ini termasuk penelitian deskriptif, yaitu dalam penelitian ini melakukan analisis hanya sampai pada taraf deskripsi, yaitu menganalisis dan menyajikan fakta secara sistematik sehingga dapat lebih mudah untuk difahami dan disimpulkan. Pengolahan datanya sering didasarkan pada analisis persentase dan analisis kecenderungan (trend) (Syaifuddin Azwar, 2001).

Penelitian disini menggunakan pendekatan penelitian kuantitatif. Pendekatan penelitian kuantitatif berlandaskan pada filsafat positivisme, digunakan untuk meneliti pada populasi atau sampel tertentu, teknik pengambilan sampel pada umumnya dilakukan secara random, pengumpulan data menggunakan instrumen penelitian, analisis data bersifat kuantitatif/statistik dengan tujuan untuk menguji hipotesis yang telah ditetapkan (Sugiyono, 2013: 14).

Konsep diri yaitu gambaran bagaimana diri diamati, dipersepsi dan dialami oleh individu. Konsep tentang diri muncul dari interaksi sosial dan akan menjadi penuntun atau berpengaruh pada tingkahlakunya. Konsep diri dapat diisyaratkan dengan tinggi-rendahnya skor total dan konsistensi jawaban yang mencakup dimensi internal dan eksternal. Dimensi internal terdiri dari: Diri-Identitas (Identity Self), DiriTingkahlaku (Behavioral Self); Diri Penilaian (Judging Self). Sedang dimensi eksternal terdiri dari: Diri-Fisik (Physical Self), DiriMoral Etik(Moral-Ethical Self), Diri-Personal (Personal Self), Diri-Keluarga (Family Self), Diri-Sosial (Social Self), Diri-Akademik/ Kerja (Academic/Work Self).

Populasi penelitian ini adalah seluruh siswa SMP se Kota Yogyakarta, baik yang bersekolahdinegerimaupundiswasta. Sampel penelitian adalah sebagian siswa SMP yang dianggap representatif mewakili populasi. Jumlah SMP Negeri di kota Yogyakarta ada sebanyak 15 sekolah, sedangkan SMP Swasta berjumlah 42 sekolah.

Rancangan sampling menggunakan teknik cluster multi stage sampling (sampling bertingkat dengan memperhatikan kelompok-kelompok). Dalam penelitian ini, ada 15 SMP Negeri dan 42 SMP Swasta. Dengan menggunakan teknik cluster multi stage sampling, diperoleh sampel SMP swasta 3, yaitu SMP Taman Dewasa Taman Siswa, SMP Muhammadiyah 3, SMP Kanisius. Sedang untuk SMP negeri diperoleh sampel 2 SMP, yaitu: SMPN 8 dan SMPN 15. Di masing-masing sekolah, diambil perwakilan kelas 1,2 dan 3 . Sehingga masing-masing sekolah diwakili oleh 3 kelas. Kelas secara menyeluruh dalam penelitian ada 15 kelas, dengan jumlah subjek 449 siswa.

Alat ukur dalam penelitian ini 
menggunakan alat ukur Tennessee Concept Scale-2. Kuesioner ini dikonstruksi dalam bentuk skala bertingkat yang memuat pernyataan-pernyataan mengenai keseimbangan konsep diri antara dimensi internal dan eksternal dari Fittz (1996) yang diadaptasi ke dalam bahasa Indonesia oleh Irene Tarakanita (tahun 2001).

Alat ukur dalam penelitian kuantitatif, reliabilitasnyadihitungdenganmenggunakan formulasi koefisien Alpha dari Cronbach, (Triyono, 2013: 26; Syaifuddin Azwar, 2013: 115). Alat ukur ini tidak diuji validitasnya, karena sudah divalidasi oleh peneliti asli.

Pengumpulan data kuantitatif dilakukan dengan angket atau kuesioner pada variabel konsep diri. Angket berjumlah 82 item.Analisis data menggunakan Teknik Analisis Statistik deskriptif dengan teknik presentase untuk konsep diri, serta dihitung keterkaitan antara aspek2 identitas, seperti kelompok sekolah, umur, jenis kelamin dan kelas dengan konsep diri menggunakan koefisien kontingensi.

\section{HASIL DAN PEMBAHASAN}

Lokasi Penelitian pada SMP-SMP di kota Yogyakarta, baik negeri maupun swasta. Subjek penelitian kota Yogyakarta berjumlah 15, sedang SMP Swasta ada 42 SMP. Berdasarkan pengambilan sampel dengan teknik cluster multi stage sampling, diperoleh jumlah sampel 449 siswa.

\section{Gambaran Identitas Subjek Penelitian (Siswa)}

Gambaran kelompok siswa, dapat di deskripsikan bahwa kelompok sekolah siswa negeri ada 184 siswa (41\%) dan siswa swasta ada 265 orang (59\%).

Gambaran kelompok umur siswa dapat dideskripsikan bahwa kelompok umur siswa yang berusia 11 tahun ada 7 orang (1.6\%); siswa yang berumur 12 tahun ada 58 orang (12.9), siswa yang berumur 13 tahun ada 149 orang (33.2\%); siswa yang berumur 14 tahun ada 167 orang (37.2\%); siswa yang berumur 15 tahun ada 60 orang (13.4\%); siswa yang berumur
16 tahun ada 6 orang (1.3\%) dan siswa yang berumur 17 tahun ada 2 orang (0.4\%). Jadi dapat disimpulkan siswa terbanyak berusia 14 tahun (167 orang: 37.2\%).

Gambaran jenis kelamin siswa dapat di deskripsikan, bahwa jenis kelamin siswa laki-laki ada sebanyak 223 orang (49.7\%); siswa perempuan ada 226 orang (50.3\%). Jadi dapat disimpulkan jenis kelamin siswa terbanyak adalah perempuan, 226 orang (50.3\%).

Gambaran Tingkat Kelas Siswadapat di deskripsikan bahwa siswa kelas VII ada sebanyak 114 orang (25.4\%); siswa kelas VIII ada sebanyak 150 orang (33.4\%) siswa kelas IX ada sebanyak 185 orang (41,2\%). Jadi dapat disimpulkan siswa yang terbanyak ada di kelas 9 (185 orang: 41.2\%).

Gambaran Konsep Diri Fisik Siswadapat di deskripsikan bahwa diri fisik siswa yang rendah ada sebanyak 199 orang (44.3\%); siswa dengan diri fisik yang tinggi ada 250 orang $(55.7 \%)$. Jadi dapat disimpulkan bahwa diri fisik siswa terbanyak adalah yang memiliki konsep diri fisik yang tinggi, yaitu 250 orang $(55 \cdot 7 \%)$.

Gambaran Konsep Diri Etik-Moral Siswadapat di deskripsikan bahwa diri etik moral siswa yang rendah ada sebanyak 220 orang (49\%); siswa dengan diri etik-moral yang tinggi ada 229 orang (51\%). Jadi dapat disimpulkan bahwa diri etik-moral siswa terbanyak adalah yang memiliki konsep diri etik-moral yang tinggi, yaitu 229 orang (51\%).

Gambaran Konsep Diri Personal Siswadapat di deskripsikan bahwa diri personal siswa yang rendah ada sebanyak 216 orang (48.1\%); siswa dengan diri personal yang tinggi ada 233 orang (51.9\%). Jadi dapat disimpulkan bahwa diri personal siswa terbanyak adalah yang memiliki konsep diri personal yang tinggi, yaitu 233 orang (59.1\%).

Gambaran konsep diri keluarga siswa dapat di deskripsikan bahwa diri keluarga siswa yang rendah ada sebanyak 192 orang (42.8\%); siswa dengan diri keluarga yang tinggi ada 257 orang (57.2\%). Jadi dapat 
disimpulkan bahwa diri keluarga siswa terbanyak adalah yang memiliki konsep diri keluarga yang tinggi, yaitu 257 orang $(57.2 \%)$.

Gambaran konsep diri sosial siswa, dapat di deskripsikan bahwa diri sosial siswa yang rendah ada sebanyak 220 orang (49\%); siswa dengan diri sosial yang tinggi ada 229 orang (51\%). Jadi dapat disimpulkan bahwa diri sosial siswa terbanyak adalah yang memiliki konsep diri sosial yang tinggi, yaitu 229 orang $(51 \%)$.

Gambaran konsep diri akademik/kerja siswa, dapat di deskripsikan bahwa diri akademik/kerja siswa yang rendah ada sebanyak 187 orang (41.6\%); siswa dengan diri akademik/kerja yang tinggi ada 262 orang (58.4\%). Jadi dapat disimpulkan bahwa diri akademik/kerja siswa terbanyak adalah yang memiliki konsep diri akademik/kerja yang tinggi, yaitu 262 orang (58.4\%).

Gambaran Konsep Diri Siswa, dapat di deskripsikan bahwa konsep diri siswa yang rendah ada sebanyak 222 orang (49.4\%); siswa dengan konsep diri yang tinggi ada 227 orang (50.6\%). Jadi dapat disimpulkan bahwa konsep diri siswa berimbang antara yang memiliki konsep diri yang rendah ( 222 orang: $49.4 \%$ ), yang memiliki konsep diri yang tinggi (yaitu 227 orang: 50.6\%).

Dari aspek-aspek konsep diri yang terdiri dari 6, maka dapat digambarkan sebagai berikut:

\section{Tabel 1. Persentase Aspek Konsep Diri}

\begin{tabular}{|c|c|c|c|c|}
\hline No & Aspek & Tinggi & Rendah & Total \\
\hline 1 & Konsep Diri Fisik & $\begin{array}{c}250 \\
(55.7 \%)\end{array}$ & $\begin{array}{c}199 \\
(44,3 \%) \\
\end{array}$ & $\begin{array}{c}449 \\
(100 \%) \\
\end{array}$ \\
\hline 2 & $\begin{array}{l}\text { Konsep diri } \\
\text { Etik-Moral }\end{array}$ & $\begin{array}{c}229 \\
(51 \%) \\
\end{array}$ & $\begin{array}{c}220 \\
(49 \%)\end{array}$ & $\begin{array}{c}449 \\
(100 \%) \\
\end{array}$ \\
\hline 3 & Konsep diri Personal & $\begin{array}{c}233 \\
(51,9 \%) \\
\end{array}$ & $\begin{array}{c}216 \\
(48,1 \%)\end{array}$ & $\begin{array}{c}449 \\
(100 \%) \\
\end{array}$ \\
\hline 4 & Konsep diri Keluarga & $\begin{array}{c}257 \\
(57,2 \%) \\
\end{array}$ & $\begin{array}{c}192 \\
(42,8 \%)\end{array}$ & $\begin{array}{c}449 \\
(100 \%)\end{array}$ \\
\hline 5 & Konsep diri Sosial & $\begin{array}{c}229 \\
(51 \%)\end{array}$ & $\begin{array}{l}220 \\
(49 \%)\end{array}$ & $\begin{array}{c}449 \\
(100 \%)\end{array}$ \\
\hline 6 & $\begin{array}{c}\text { Konsep diri } \\
\text { akademik / kerja }\end{array}$ & $\begin{array}{c}262 \\
(58,4 \%) \\
\end{array}$ & $\begin{array}{c}187 \\
(41,6 \%) \\
\end{array}$ & $\begin{array}{r}449 \\
(100 \%) \\
\end{array}$ \\
\hline
\end{tabular}

Dari aspek-aspek konsep diri tersebut di atas, yang paling menonjol adalah konsep diri kerja/akademik, yaitu yang memiliki konsep diri kerja/akademik yang tinggi sebanyak 262 siswa (58.4\%). Yang kedua terbanyak adalah konsep diri keluarga yang tinggi sebanyak 257 siswa (57.2\%). Sedang yang ke tiga terbanyak adalah konsep diri fisik yang tinggi, yaitu 250 siswa (55.7\%). Untuk aspek konsep diri yang rendah, yang terbanyak adalah konsep diri etik moral, 220 siswa (49\%), konsep diri sosial, 220 siswa (49\%), serta konsep diri personal, 216 siswa (48.1\%).

Keterkaitan antara Kelompok Sekolah dengan Konsep Diri Siswa. D a r i ta bu la si silang antara kelompok sekolah dengan konsep diri siswa, diperoleh hasil bahwa siswa sekolah negeri (1) yang memiliki konsep diri rendah ada sebanyak 93 orang(20.7\%); siswa sekolah negeri dengan konsep diri yang tinggi ada 91 orang (20.3\%). Sedangkan siswa sekolah swasta dengan konsep diri rendah ada 129 orang (28.7\%); siswa sekolah swasta dengan onsep diri yang tinggi ada 136 orang (30.3\%). Jadi dapat disimpulkan, siswa SMP ditinjau dari sekolah dan konsep dirinya, yang terbanyak adalah siswa sekolah swasta dengan konsep diri yang tinggi 136 orang (30.3\%).

Selain itu dari pengukuran tentang keterkaitan kelompoksekolahdengan konsep diri yang dilakukan dengan teknik Koefisien Kontingensi diperoleh hasil C: o,o18, sign: o,698. Hal ini menggambarkan bahwa tidak terdapat hubungan yang signifikan antara kelompok sekolah dengan konsep diri siswa. Dari hasil di atas, dapat disimpulkan, bahwa tidak terdapat keterkaitan antara siswa kelompok sekolah swasta maupun negeri dengan konsep dirinya.

Keterkaitan antara Umur Siswa dengan Konsep Diri Siswa.Dari tabulasi silang antara umur dengan konsep diri siswa, diperoleh hasil bahwa siswa yang berumur 11 tahun yang memiliki konsep diri rendah ada sebanyak 3 orang $(0.7 \%)$ dan siswa berumur 11 tahun dengan konsep diri yang tinggi ada 4 orang (o.9\%). Sedangkan siswa yang berumur 12 tahun yang memiliki konsep diri rendah ada sebanyak 3o orang (6.7\%), dan siswa berumur 12 tahun dengan konsep diri yang tinggi ada 28 orang (6.2\%); siswa yang berumur 13 tahun dengan konsep diri yang rendah ada 70 orang (15.6\%), dan siswa yang berumur 13 tahun dengan konsep diri yang tinggi ada 79 orang (17.6\%). Siswa yang berumur 14 tahun 
dengan konsep diri yang rendah ada 82 orang $(18.3 \%)$, dan siswa yang berumur 14 tahun dengan konsep diri yang tinggi ada 85 orang (18.9\%). Siswa yang berumur 15 tahun dengan konsep diri yang rendah ada 32 orang (7.1\% ), dan siswa yang berumur 15 tahun dengan konsep diri yang tinggi ada 28 orang $(6.2 \%)$. Siswa yang berumur 16 tahun dengan konsep diri yang rendah ada 4 orang (0.9\%), dan siswa yang berumur 16 tahun dengan konsep diri yang tinggi ada 2 orang (0.4\%). Siswa yang berumur 17 tahun dengan konsep diri yang rendah ada 1 orang ( $0.2 \%)$, dan siswa yang berumur 17 tahun dengan konsep diri yang tinggi ada 1 orang (o.2\%). Jadi dapat disimpulkan, siswa SMP ditinjau dari umur dan konsep dirinya, yang terbanyak adalah siswa yang berumur 14 tahun dengan konsep diri yang tinggi 85 orang (18.9\%).

Selainitu dari pengukuran tentang keterkaitan umur dengan konsep diri yang dilakukan dengan teknik Koefisien Kontingensi diperoleh hasil C: o,o61, sign: o,946. Hal ini menggambarkan bahwa tidak terdapat hubungan yang signifikan antara umur dengan konsep diri siswa. Dari hasil di atas, dapat disimpulkan, bahwa tidak terdapat keterkaitan antara umur siswa dengan konsep dirinya.

Keterkaitan antara Jenis Kelamin Siswa dengan Konsep Diri Siswa. Dari tabulasi silang antara jenis kelamin dengan konsep diri siswa, diperoleh hasil bahwa siswa lakilaki yang memiliki konsep diri rendah ada sebanyak 99 orang(22\%); siswa laki-laki dengan konsep diri yang tinggi ada 124 orang (27.6\%). Sedangkan siswa perempuan dengan konsep diri rendah ada 123 orang (27.4\%); siswa perempuan dengan konsep diri yang tinggi ada 103 orang (22.9\%). Jadi dapat disimpulkan, siswa SMP ditinjau dari jenis kelamin dan konsep dirinya, yang terbanyak adalah siswa laki-laki dengan konsep diri yang tinggi, 124 orang (27.6\%), dan siswa perempuan dengan konsep diri yang rendah sebanyak 123 orang (27.4\%).

Selain itu dari pengukuran tentang keterkaitan jenis kelamin dengan konsep diri yang dilakukan dengan teknik Koefisien Kontingensi diperoleh hasil C: o,1, sign: o,034.
Hal ini menggambarkan bahwa ada hubungan yang signifikan antara jenis kelamin dengan konsep diri siswa. Dari hasil di atas, dapat disimpulkan, bahwa ada keterkaitan antara jenis kelamin siswa dengan konsep dirinya.

Keterkaitan antara Kelas dengan Konsep Diri Siswa. Dari tabulasi silang antara kelas dengan konsep diri siswa, diperoleh hasil bahwa kelas 7 yang memiliki konsep diri rendah ada sebanyak 54 orang(12\%); kelas 7 dengan konsep diri yang tinggi ada 6o orang (13.4\%). Sedangkan kelas 8 dengan konsepdiri rendah ada 71 orang (15.8\%); kelas 8 dengan konsep diri yang tinggi ada 79 orang (17.6\%). Kelas 9 dengan konsep diri yang rendah ada 97 orang (21.6\%) dan kelas 9 dengan konsep diri yang tinggi ada 88 orang (19.6\%). Jadi dapat disimpulkan, siswa SMP ditinjau dari kelas dan konsep dirinya, yang terbanyak adalah kelas 9 dengan dengan konsep diri yang rendah, 97 orang (21.6\%).

Selain itu dari pengukuran tentang keterkaitan kelas dengan konsep diri yang dilakukan dengan teknik Koefisien Kontingensi diperoleh hasil C: o,050, sign: 0,570.

Hal ini menggambarkan bahwa tidak terdapat hubungan yang signifikan antara kelas dengan konsep diri siswa. Dari hasil di atas, dapat disimpulkan, bahwa tidak ada keterkaitan antara kelas siswa dengan konsep dirinya.

\section{Model Pendampingan bagi Remaja Siswa}

Dari hasil diatas, dalam kaitan dengan pendampingan bagi siswa, maka adabeberapa hal yang dapat dirancang untuk mengembangkan konsep diri siswa terutama dalam kaitan dengan komunikasi interpersonalnya, dengan didukung oleh gaya interaksi pendamping kepada siswa dan jenis layanan bimbingan yang dapat dikembangkan.

Mengingat pembentukan konsep diri pada siswa, sangat tergantung pada aspek2 internal dan eksternal individu. Aspek internal dalam penelitian ini adalah konsep 
diri siswa, sedang aspek eksternal adalah orangtua dan guru. Dengan hasil konsep diri yang sudah diteliti, maka aspek konsep diri yang paling menonjol tinggi adalah aspek konsep diri akademik/kerja, kemudian konsep diri keluarga dan konsep diri fisik. Sedangkan aspek konsep diri yang rendah pada konsep diri etik/moral, konsep diri sosial dan konsep diri personal.

Dari sisi komunikasi interpersonal, karena terdapat hubungan yang erat secara konseptual antara konsep diri dengan komunikasi interpersonal (Jalaludin Rakhmat, 2015: 102); maka bagi pendamping remaja siswa, yaitu guru atau orang tua atau teman sebaya lebih dewasa, perlu memperhatikan aspek-aspek:a) konsep diri siswa (positif atau negatif);b) remaja perlu diajakmembuka diri; c) remaja perlu ditumbuhkan kepercayaan dirinya; d) remaja perlu dimampukan untuk selektif apa yang terterpa pada dirinya.

Dari sisi gaya interaksi, gaya interaksi yang serta digunakan pendekatan yang mendorong (enabling) dari pendamping perlu dikembangkan, karena gaya interaksi ini yang memadai untuk perkembangan konsep diri siswa remaja.

Sedang dari sisi layanan bimbingan dan konseling, bisa dibentuk bimbingan kelompok dan bimbingan individual, dengan langkah-langkah sebagai berikut: siswa dalam kelas dimasukkan dalam beberapa kelompok; Kemudian siswa diberi angket terbuka untuk mengisi hal-hal yang berkaitan dengan konsep diri; Setelah mengisi, lalu siswa diminta berdiskusi dalam kelompok; Hasil dari kelompok, di presentasikan dalam pleno kelas; Guru mencermati individuindividu yang dirasa memiliki keistimewaan atau kekhususan dalam konsep diri untuk kemudian dibimbing secara individual.

\section{Potret Konsep Diri}

Konsep diri siswa SMP se kota Yogyakarta dalam penelitian ini terdapat konsep diri siswa yang rendah ada sebanyak 222 orang (49.4\%); siswa dengan konsep diri yang tinggi ada 227 orang (50.6\%). Jadi dapat disimpulkan bahwa konsep diri siswa berimbang antara yang memiliki konsep diri yang rendah ( 222 orang: 49.4\%), yang memiliki konsep diri yang tinggi (yaitu 227 orang: 50.6\%). Dapat dimaklumi, jika pada usia ini, siswa SMP masih banyak yang memiliki konsep diri rendah, karena memang kognisinya belum berkembang begitu sempurna, sehingga perkembangan kognisi yang belum optimal, menyebabkan siswa belum memahami secara mendalam apa yang dialami atau bagaimana dirinya. Konsep diri akan tumbuh jika mendapat stimulan dari lingkungan, terutama untuk masa remaja awal, remaja membutuhkan dukungan lingkungan dari orangtua dan orang dewasa. Namun mungkin karena ketiadaan dukungan dari orang-orang di lingkungan menjadikan siswa remaja tidak mendapatkan sugesti yang cukup, dan hal ini dapat memberikan kontribusi pada konsep diri yang kurang.

Dari aspek-aspek konsep diri, yang paling menonjol adalah konsep diri kerja/ akademik, yaitu yang memiliki konsep diri kerja/akademik yang tinggi sebanyak 262 siswa (58.4\%). Yang kedua terbanyak adalah konsep diri keluarga yang tinggi sebanyak 257 siswa (57.2\%). Sedang yang ke tiga terbanyak adalah konsep diri fisik yang tinggi, yaitu 250 siswa (55.7\%). Untuk aspek konsep diri yang rendah, yang terbanyak adalah konsep diri etik moral, 220 siswa (49\%), konsep diri sosial, 220 siswa (49\%), serta konsep diri personal, 216 siswa (48.1\%). Dari hasil ini, konsep diri akademik/kerja menjadi konsep diri yang paling banyak dimiliki siswa remaja (58.4\%). Meski masa remaja awal, kebanyakan remaja masih ada di sekolah, namun banyak juga yang sudah putus sekolah. Saat remaja masih sekolah, aspirasi terbesar setelah sekolah adalah bekerja, hal ini adalah sebuah kewajaran. Dengan bekerja, seseorang akan merasa terjamin kehidupannya, sehingga konsep diri yang tinggi yang tergambar dalam diri siswa remaja ini, bisa jadi merupakan harapan bisa juga merupakan kenyataan yang terjadi riil pada siswa remaja.

Selanjutnya untuk konsep diri yang dimiliki terbanyak setelah konsep diri 
akademik/kerja adalah konsep diri keluarga. Remaja awal, siswa SMP dalam hal ini dianggap memiliki konsep diri keluarga yang tinggi $(57.2 \%)$, hal ini bisa berarti, bahwa remaja tersebut memiliki keluarga yang bahagia, yang menyenangkan dan memberi kenyamanan. Selanjutnya konsep diri yang terbanyak ketiga adalah konsep diri fisik (55.7\%), hal ini bisa dipahami, mengingat siswa SMP berusia antara 11 tahun-15 tahun, di masa ini remaja baru berkembang fisiknya, diawali dengan pubertas dan akhirnya akan mencapai kemasakan fisik dan seksual. Untuk remaja yang 'mampu' melewati masa kritis pubertas, dapat dipastikan akan tumbuh lebih sehat daripada remaja yang kurang mampu melewati pubertasnya dengan baik. Namun tumbuh sehatnya remaja di masa ini, juga tergantung pada bagaimana lingkungannya memperlakukan remaja. Jika lingkungan tidak mendukung, maka bisa jadi tidak tercapai perkembangan yang sehat.

Hasilyanglainadalahterdapatkonsepdiri yang rendah, yang terbanyak adalah konsep diri etik moral, 220 siswa (49\%), konsep diri sosial, 220 siswa (49\%), serta konsep diri personal, 216 siswa (48.1\%). Konsep diri etik-moral adalah persepsi diri ditinjau dari standar pertimbangan nilai-nilai moral dan etika. Pada siswa SMP di Yogyakarta, yang menunjukkan konsep diri yang rendah yang terbanyak (49\%), menjadi menarik jika dikaitkan dengan konsep Kohlberg tentang perkembangan penalaran moral. Menurut Kohlberg, di usia remaja, biasanya remaja dimasukkan dalam tahap 3 perkembangan penalaran moral, yaitu tahap good boy, good girl. Hal ini berarti, remaja dalampenalaran moralnya, dalam mempertimbangkan baik dan buruk, masih menyesuaikan dengan harapan sosial kepadanya. Artinya dia akan bertindak atau berbuat baik sesuai dengan harapan masyarakat kepadanya. Sehingga saat remaja siswa mempersepsi dirinya dalam konteks moral, maka mereka masih kebingungan dalam memahami standar pertimbangan nilai moral dan etika, apalagi untuk menerapkannya. Sehingga dapat dipahami, konsep diri etik-moral siswa yang kebanyakan rendah menunjukkan belum pahamnya remaja tentang konsep diri moral dan penerapannya di dunia nyata.

Konsep diri siswa yang rendah selain konsepdirietik-moraladalahkonsepdirisosial (49\%). Konsep diri sosial adalah penilaian individu terhadap dirinya dalam interaksinya dengan orang lain dalam lingkungan yang lebih luas. Dalam hal remaja siswa SMP, pada saat ini perkembangan yang paling menonjol adalah perkembangan fisik dan seksualnya, sehingga perkembangan sosialnya belum banyak diperhatikan. Maka jika remaja siswa SMP konsep diri sosialnya rendah, hal ini disebabkan karena fokus perhatian remaja pada kondisi fisik dan seksualnya yang berubah. Biasanya di masa remaja tengah, baru remaja bisa memfokuskan pada perkembangan yang lain, dan hal ini akan mendukung konsep dirinya pula.

Selanjutnya, konsep diri yang rendah yang lain adalah konsep diri personal (48.1\%). Konsep diri personal adalah keadekuatan perasaan individu terhadap nilai-nilai pribadi, terlepas dari keadaan fisik dan hubungan dengan orang lain. Konsep diri personal pada remaja siswa SMP juga rendah, hal ini disebabkan sekali lagi karena fokus remaja siswa baru pada masalah fisik dan seksual, hal sosial, etik-moral dan personal belum menjadi perhatian utama pada remaja awal, siswa SMP ini.

Dalam hal keterkaitan antara kelompok sekolah yaitu sekolah negeri dan swasta dengan konsepdirinya, yangterbanyakadalah siswa sekolah swasta dengan konsep diri yang tinggi 136 orang (30.3\%). Dari pengukuran tentang keterkaitan kelompok sekolah dengan konsep diri yang dilakukan dengan teknik Koefisien Kontingensi diperoleh hasil C: o,o18, sign: o,698.Hal ini menggambarkan bahwa tidak terdapat hubungan yang signifikan antara kelompok sekolah dengan konsep diri siswa. Jadi dapat disimpulkan, bahwa tidak terdapat keterkaitan antara siswa kelompok sekolah swasta maupun negeri dengan konsep dirinya. Remaja SMP swasta yang konsep dirinya tinggi dalam penelitian ini terbanyak jumlahnya, hal ini menggambarkan remaja SMP swasta lebih 
banyak yang memiliki konsep diri yang tinggi. Barangkali ini disebabkan SMP Swasta yang terpilih adalah SMP yang berafiliasi ke agama tertentu (Islam dan Katolik). Biasanya dalam sekolah-sekolah yang afiliasinya sama, cenderung memiliki kepercayaan diri yang tinggi, karena ada perasaan in-group. Sedang hasil yang menyatakan tidak ada keterkaitan antara kelompok sekolah dengan konsep diri remaja siswa, menunjukkan bahwa baik siswa yang bersekolah di sekolah negeri maupun swasta konsep dirinya sama.

Dalam hal keterkaitan antara umur siswa dengan konsep dirinya, yang terbanyak adalah siswa yang berumur 14 tahun dengan konsep diri yang tinggi 85 orang (18.9\%). Dari pengukuran tentang keterkaitan umur dengan konsepdiri yang dilakukan dengan teknik Koefisien Kontingensi diperoleh hasil C: o,o61, sign: o,946. Hal ini menggambarkan bahwa tidak terdapat hubungan yang signifikan antara umur dengan konsep diri siswa. Jadi dapat disimpulkan, bahwa tidak terdapat keterkaitan antara umur siswa 11 tahun, 12 tahun, 13 tahun, 14 tahun, 15 tahun, 16 tahun dan 17 tahun dengan konsep diri. Remaja SMP yang berumur 14 tahun yang konsep dirinya tinggi dalam penelitian ini terbanyak jumlahnya, hal ini menggambarkan remaja berumur 14 tahun lebih banyak yang memiliki konsep diri yang tinggi. Sedang hasil yang menyatakan tidak ada keterkaitan antara umur dengan konsep diri remaja siswa, menunjukkan bahwa baik siswa yang berumur 11, 12, 13, 14, 15, 16, 17 tahun konsep dirinya sama.

Dalam hal keterkaitan antara jenis kelamin siswa dengan konsep dirinya, yang terbanyak adalah siswa laki-laki dengan konsep diri yang tinggi, 124 orang $(27,6 \%)$, dan siswa perempuan dengan konsep diri yang rendah sebanyak 123 orang $(27,4 \%)$. Dari pengukuran tentang keterkaitan jenis kelamin dengan konsep diri yang dilakukan dengan teknik Koefisien Kontingensi diperoleh hasil C: o,1, sign: o,o34.Hal ini menggambarkan bahwa terdapat hubungan yang signifikan antara jenis kelamin dengan konsep diri siswa.

Jadi dapat disimpulkan, bahwa terdapat keterkaitanantarajenis kelamin siswa dengan konsep diri. Remaja SMP laki-laki yang konsep dirinya tinggi dalam penelitian ini terbanyak jumlahnya, hal ini menggambarkan remaja laki-laki lebih banyak yang memiliki konsep diri yang tinggi. Namun juga terdapat hasil yang lain, yaitu remaja perempuan yang konsep dirinya rendah juga banyak jumlahnya. Jadi justru antara remaja laki-laki dengan perempuan terdapat kontradiksi yang menyolok, yaitu remaja laki-laki banyak yang memiliki konsep diri tinggi, sedang remaja perempuan memiliki konsep diri rendah. Bisa jadi, remaja perempuan lebih peduli pada perkembangannya, terutama perkembangan fisiknya, dan hal ini yang memicu remaja perempuan untuk merasa 'rendah' dalam konsep dirinya, terutama konsep diri fisik, selain di saat ini adalah saat krisis bagi remaja dalam menghadapi perubahan tubuh kanakkanaknya menuju ke tubuh dewasa. Sedang pada remaja siswa laki-laki bisa jadi kurang atau belum matang untuk memikirkan tentang perubahan tubuhnya, sehingga konsep dirinya lebih tinggi. Sedang hasil yang menyatakan ada keterkaitan antara jenis kelamin dengan konsep diri remaja siswa, hal ini menunjukkan bahwa antara jenis kelamin laki-laki dan perempuan ada perbedaan dalam konsep dirinya.

Dalam hal keterkaitan antara kelompok kelas siswa dengan konsep dirinya, yang terbanyak adalah kelas 9 dengan dengan konsep diri yang rendah, 97 orang (21.6\%). Dari pengukuran tentang keterkaitan kelas dengan konsepdiri yang dilakukan dengan teknik Koefisien Kontingensi diperoleh hasil C: o,050, sign : 0,570. Hal ini menggambarkan bahwa terdapat hubungan yang tidak signifikan antara kelompok kelas 7 , kelas 8 dan kelas 9 dengan konsepdirisiswa. Jadi dapat disimpulkan, bahwa tidak terdapat keterkaitan antara kelompok kelas siswa dengan konsep diri. Remaja SMP kelas 9 yang konsep dirinya rendah dalam penelitian ini terbanyak jumlahnya, hal ini menggambarkan remaja siswa kelas 9 lebih banyak yang memiliki konsep diri yang rendah. Sedang hasil yang menyatakan tidak ada keterkaitan antara kelompok kelas 
dengan konsep diri remaja siswa, hal ini menunjukkan bahwa antara kelompok kelas tidak ada perbedaan dalam konsep dirinya.

\section{SIMPULAN}

Konsep diri siswa berimbang antara yang memiliki konsep diri yang rendah (222 orang: $49.4 \%$ ), dengan yang memiliki konsep diri yang tinggi (yaitu 227 orang: 50.6\%).Dari aspek-aspek konsep diri, diperoleh hasil, yamg memiliki:konsep diri kerja/akademik yang tinggi sebanyak 262 siswa (58.4\%); konsep diri keluarga yang tinggi sebanyak 257 siswa (57.2\%); konsep diri fisik yang tinggi, yaitu 250 siswa (55.7\%); konsep diri etik moral yang rendah ada 220 siswa (49\%); konsep diri sosial yang rendah ada 220 siswa (49\%); konsep diri personal yang rendah ada 216 siswa $(48.1 \%)$.

Dalam hal keterkaitan antara kelompok sekolah yaitu sekolah negeri dan swasta dengan konsep dirinya, yang terbanyak adalah siswa sekolah swasta dengan konsep diri yang tinggi 136 orang (30.3\%). Pengukuran tentang keterkaitan kelompok sekolah dengan konsep diri,diperoleh hasil C: o,o18, sign: o,698. Hal ini menggambarkan bahwa tidak terdapat hubungan yang signifikan antara kelompok sekolah dengan konsep diri siswa.

Dalam hal keterkaitan antara umur siswa dengan konsep dirinya, yang terbanyak adalah siswa yang berumur 14 tahun dengan konsep diri yang tinggi 85 orang (18.9\%). Pengukuran tentang keterkaitan umur dengan konsep diri diperoleh hasil C: o,o61, sign: 0,946 . Hal ini menggambarkan bahwa tidak terdapat hubungan yang signifikan antara umur dengan konsep diri siswa.

Dalam hal keterkaitan antara jenis kelamin siswa dengan konsep dirinya, yang terbanyak adalah siswa laki-laki dengan konsep diri yang tinggi, 124 orang (27.6\%), dan siswa perempuan dengan konsep diri yang rendah sebanyak 123 orang (27.4\%). Pengukuran tentang keterkaitan jenis kelamin dengan konsep diri diperoleh hasil C: o,1, sign: o,034. Hal ini menggambarkan bahwa terdapat hubungan yang signifikan antara jenis kelamin dengan konsep diri siswa

Dalam hal keterkaitan antara kelompok kelas siswa dengan konsep dirinya, yang terbanyak adalah kelas 9 dengan dengan konsep diri yang rendah, 97 orang (21.6\%). Pengukuran tentang keterkaitan kelas dengan konsep diri diperoleh hasil C: 0,050, sign: 0,570. Hal ini menggambarkan bahwa terdapat hubungan yang tidak signifikan antara kelompok kelas 7, kelas 8 dan kelas 9 dengan konsep diri siswa.

Pendampingan bagi remaja siswa SMP di Yogya, dengan memperhatikan kondisi konsep diri siswa. Konsep diri yang cenderung rendah adalah konsep diri etikmoral, sosial dan personal, maka digunakan pendekatan bagi pendamping: a) dari sisi komunikasi interpersonal: Nubuat yang dipenuhi sendiri; membuka diri; percaya diri; dan selektivitas; b) dari sisi gaya interaksi, dengan mengembangkan gaya interaksi yang mendorong (enabling); c) dari sisi layanan bimbingan dan konseling dengan membentuk bimbingan kelompok dan bimbingan individual. 


\section{DAFTAR PUSTAKA}

Berk, L.E. (1996). Infants, Children and Adolesence.. USA: Allyn \& Bacon

Fitzz,W.H. (1971). The Self Concept and Behaviour: Overview and Supplement. Research Monograph. No VII, Library of Congress Catalog Number 72-80269. California.

Hendriati Agustiani. (2009). Psikologi Perkembangan. Bandung : PT Refika Aditama

Hurlock, Elizabeth B. (1980). Psikologi Perkembangan, Suatu Pendekatan Sepanjang Rentang Kehidupan (edisi ke lima). Jakarta : Erlangga

Hall, S. Calvin \& Lindzey. G. (1978). Theories of Personality. New York: John Wiley \& Sons.

Irene Tarakanita. (2001). "Hubungan Status Identitas Etnik dan Konsep Diri Mahasiswa pada Kelompok Etnik Sunda dan Kelompok Etnik Cina”.Tesis.
Bandung: PPS UNPAD.

Jalaludin Rakmat. (2015). (ed 30). Psikologi Komunikasi. Bandung: Remaja Rosda Karya.

Papalia. D.E \& S.W. Olds. (1993). A Child's World, Infancy Through Adolesence.. USA: Mc. Graw-Hill, Inc.

Riswandi. (2013). Psikologi Komunikasi. Yogyakarta: Graha Ilmu.

Steinberg, L. (1993). Adolesence. New York: Mc Graw Hill, Inc.

Syaifuddin Azwar. (2013). PenyusunanSkala Psikologi. Yogyakarta: Pustaka Pelajar.

Triyono. (2013). Metodologi Penelitian Pendidikan. Yogyakarta: Penerbit Ombak.

Sumber Internet :

http://journalbuddies.com/self-esteemresource/journal-writing-improvesself-esteem/ 